\title{
An Early Collection of the Red Alga Mikamiella ruprechtiana Made by Carl Merck on the Billings Expedition to Alaska (1785-94)
}

\author{
MICHAEL J. WYNNE ${ }^{1}$
}

(Received 13 January 2006; accepted in revised form 5 April 2006)

\begin{abstract}
A number of original watercolored illustrations of North Pacific marine algae accompanied by the original algal specimens are deposited in the State Botanical Collection, National Herbarium of Victoria, Australia. These illustrations were executed by W.G. Tilesius, surgeon-naturalist-artist on the Krusenstern Expedition (1803-06). One of these illustrated specimens was collected in the period 1790-91 on Unalaska Island, the Aleutian Islands, by C.H. Merck, naturalist-botanical collector on the Billings Expedition (1785-94). This marine alga, given the manuscript name "Palmetta aleutica" by Tilesius, is one of the earliest known specimens of marine algae collected from Alaskan waters. Its identity is Mikamiella ruprechtiana.
\end{abstract}

Key words: Billings Expedition, early collection, Krusenstern Expedition, marine algae, Merck, Mikamiella, red algae, Tilesius, Unalaska

RÉSUMÉ. Un certain nombre d'aquarelles originales d'algues marines du Pacifique nord accompagnées de spécimens d'algues font partie de la collection botanique d'État du National Herbarium de Victoria, en Australie. Ces illustrations ont été réalisées par W.G. Tilesius, chirurgien, naturaliste et artiste de l'expédition Krusenstern (1803-1806). Un des spécimens illustrés a été recueilli pendant la période de 1790-1791 sur l'île d'Unalaska, dans les îles Aléoutiennes, par C.H. Merck, naturaliste et collectionneur botanique de l'expédition Billings (1785 - 1794). Cette algue marine, que Tilesius a nommée «Palmetta aleutica », constitue l'un des premiers spécimens connus d'algues marines provenant des eaux alaskiennes. Son identité est Mikamiella ruprechtiana.

Mots clés : expédition Billings, première collection, expédition Krusenstern, algue marine, Merck, Mikamiella, algue rouge, Tilesius, Unalaska

Traduit pour la revue Arctic par Nicole Giguère.

In 1981 Mrs. Doris Sinkora, then curator of algae at the National Herbarium of Victoria (Herbarium Code: MEL), Australia, called my attention to a number of handsomely illustrated watercolored plates of seaweeds, mostly from the North Pacific. Each of these plates, at least seven in total, was accompanied by a pressed herbarium specimen of the marine alga that was depicted in the plate. These specimens and plates had come to be deposited in the holdings of MEL through the purchase of the personal herbarium of O.W. Sonder (Ducker, 1981). The plates were executed by Wilhelm Gottlieb Tilesius (Seeman, 1857), who had served as surgeon, naturalist, and artist on a voyage under the command of Captain Adam I. Krusenstern, the first Russian to circumnavigate the globe (Krusenstern, 1813; Löwenstern, 2003). The Tsar recognized the services of Tilesius by granting him nobility, his modified surname becoming Tilesius von Tilenau. His observations on natural history made during the voyage were published in St. Petersburg (Tilesius von Tilenau, 1813). Also on that voyage was academician G.H. Langsdorff (Langsdorff, 1813-14, 1993), who collected plants, including seaweeds.
The identity of one of these algal specimens with an accompanying illustration is the subject of this note. The label provided by Doris Sinkora contained the following information:

[Delesseriaceae indet. (?Phycodrys sp.)]

As Palmetta aleutica Tilesius ined. with water colour illustration and a long manuscript description in an unknown hand. Labelled by Tilesius "Palmetta aleutica cum 2 fructicationibus in medio pseudonervo frondis. a Merckis ad Unalaschkam lecta. Conf. Tab. meam XV.fig. 2, 3. cum observationibus."

(Tilesius plates were not published).

(Merck coll. Aleutian Is. 1786-1798)

MEL 516218. Herb. Sonder.

The accompanying watercolored plate is MEL 2289186. The evidence points to Tilesius as having provided the manuscript name Palmetta aleutica, a name that apparently was never validated by publication. The information on the label indicates that the specimen was collected by Merck from Unalaska, Aleutian Islands, Alaska. These

\footnotetext{
${ }^{1}$ Department of Ecology and Evolutionary Biology and Herbarium, University of Michigan, Ann Arbor, Michigan 48109, U.S.A.; mwynne@umich.edu

(C) The Arctic Institute of North America
} 
clues were sufficient for me to determine that the collector was Carl Heinrich Merck, who, along with his assistant John Mains, was a naturalist and botanical collector on the Billings' "Northeastern Secret Geographical and Astronomical Expedition" of 1785-94 (Hultén, 1940). Captain Joseph Billings, an English navigator, had earlier accompanied Captain James Cook on his third voyage to the Pacific, and subsequently entered the Russian navy, initially as a lieutenant. In 1785, Empress Catherine II of Russia, acting for her government, commissioned Billings to command an expedition to search for the Northeast Passage, with the Russian officer Gavril Sarychev [also Sarichef, Sarichev, and Sarytschew] as his deputy.

In addition to his orders from the Empress, Captain Billings received secret instructions from the Admiralty College in St. Petersburg to head a geographical and astronomical expedition to the northeastern extremities of Russia (Tikhmenev, 1978). Sarychev, who was both navigator and hydrographer on the voyage, succeeded in mapping the coastline of the Sea of Okhotsk, the Chukotka Peninsula of eastern Siberia, and the Aleutian Islands, including Unalaska and Kodiak islands, as well as describing the Pribilof Islands and St. Matthew and St. Lawrence islands in the northern Bering Sea. Sarychev's journal, originally published in St. Petersburg in 1802, was later published in English translation (Sarychev, 1806-07).

Another first-person account of the Billings' expedition was by Martin Sauer (1802), who had served as Billings' secretary and translator. Sauer's account includes the "Instructions of Her Imperial Majesty" to Mr. Joseph Billings and also her "Instructions for the Naturalist, Mr. Patrin." This was the French botanist, Eugène L.M. Patrin, whom Peter Simon Pallas had nominated to serve as the naturalist. But Patrin became too ill in Irkutsk to participate in the voyage, and so Merck took his place. Article V of the instructions to the expedition's naturalist was to "particularly attend to trees, shrubs, land and water plants; preserving as many specimens as possible, particularly of any that are extraordinary or new" (Sauer, 1802). Because Patrin was unable to participate, the botanical results of the Billings Expedition have been characterized as disappointing (Rowell, 1973).

Leaving St. Petersburg in the autumn of 1785, the party went overland to Irkutsk, all arriving safely by February 1786. The party organized nine boats for the trip down the Lena River. They arrived at Yakutsk by late May. From there the group procured pack-horses for the long overland journey to the Pacific, arriving at the village of Okhotsk in July. Two small ships were constructed that winter (178687), and on 25 May 1787 the ships descended the Kolyma River to its mouth on the Arctic Ocean. The expedition explored the Siberian coast, traveling eastward until ice blocked their way and forced them to return.

It appears that Merck spent the winter of 1787-88 at Yakutsk (Merck, 1980). Two new ships were built in Okhotsk over the winter of 1788-89. These two large vessels, the Slava Rossii (Glory of Russia) and the Dobraia
Namerenia (Good Intent), were launched in August 1789. The latter vessel soon went aground on the bar at Okhotsk, but the Slava Rossii set sail in September 1789 and reached Petropavlovsk on Avacha Bay, on the east coast of the Kamchatka Peninsula, where the party overwintered. In early May 1790, the Slava Rossii left Petropavlovsk, sailing eastward and skirting the Aleutian Islands. Observations were made on Unalaska from 4 June to 11 June 1790. The ship returned to Petropavlovsk to overwinter (1790 91), and a new vessel, the Chornie Orel (Black Eagle), was constructed. In May 1791, the two ships, the Chornie Orel under the command of Captain Hall and the Slava Rossii commanded by Billings, sailed for America from Avacha Bay. From Sauer's (1802) account of the expedition, as well as Merck's (1980) own account, we know that Merck, on board the Slava Rossii, visited Unalaska Island a second time from 21 June to 4 July 1791 . The ships then sailed north, making a stop at St. Lawrence Island, and on July 28 they reached Cape Rodney, Alaska, where Billings, Merck, and others went ashore. It was the first time Europeans had set foot on the North American mainland in the area of the Bering Strait (Merck, 1980).

Reaching the Chukotka Peninsula of Russia, the two ships left off Captain Billings and a dozen crew members, including Merck, to travel by land (even using reindeer) to St. Petersburg, which they eventually reached in March 1793. The Slava Rossii, under Sarychev's command, and the Chornie Orel, commanded by Hall, returned to spend a very difficult winter (1791-92) on Unalaska Island, where many died of scurvy. The survivors returned to St. Petersburg in the spring of 1793, when an official order ended the long expedition.

According to Hultén $(1937,1940,1960)$, a few of Merck's collections are deposited in the Komarov Botanical Institute (LE) in St. Petersburg, the Natural History Museum (BM), London, and the Botanische Museum Berlin-Dahlem (B), although many Berlin holdings were destroyed by bombing at the end of World War II. No attempt was made to search for other collections made by Merck or to verify their presence in these herbaria.

Merck (1980) included a lengthy list of names of land plants, identifying them by genus and species names, and often providing the names used by the indigenous people. Compiling a list of the indigenous vocabulary was one of the main tasks undertaken by Merck. On the second visit to Unalaska, Merck observed that the natives dried seaweed, "J-aku," for the winter, and that the dried seaweed was cut up, cooked in combination with fresh or dried fish, and also used with bacon or oil. So the evidence is that Merck was on Unalaska Island in 1790 and in 1791, making collections and observations of the plants. Sauer (1802) often referred to Merck as leaving the ship to observe and collect "natural curiosities." Sarychev (1806) told of Merck's going ashore at Unalaska to make plant collections. According to Sarychev (1807:80), Merck was a man who combined "an almost puerile timidity with extraordinary intelligence." Merck learned the Yakut 


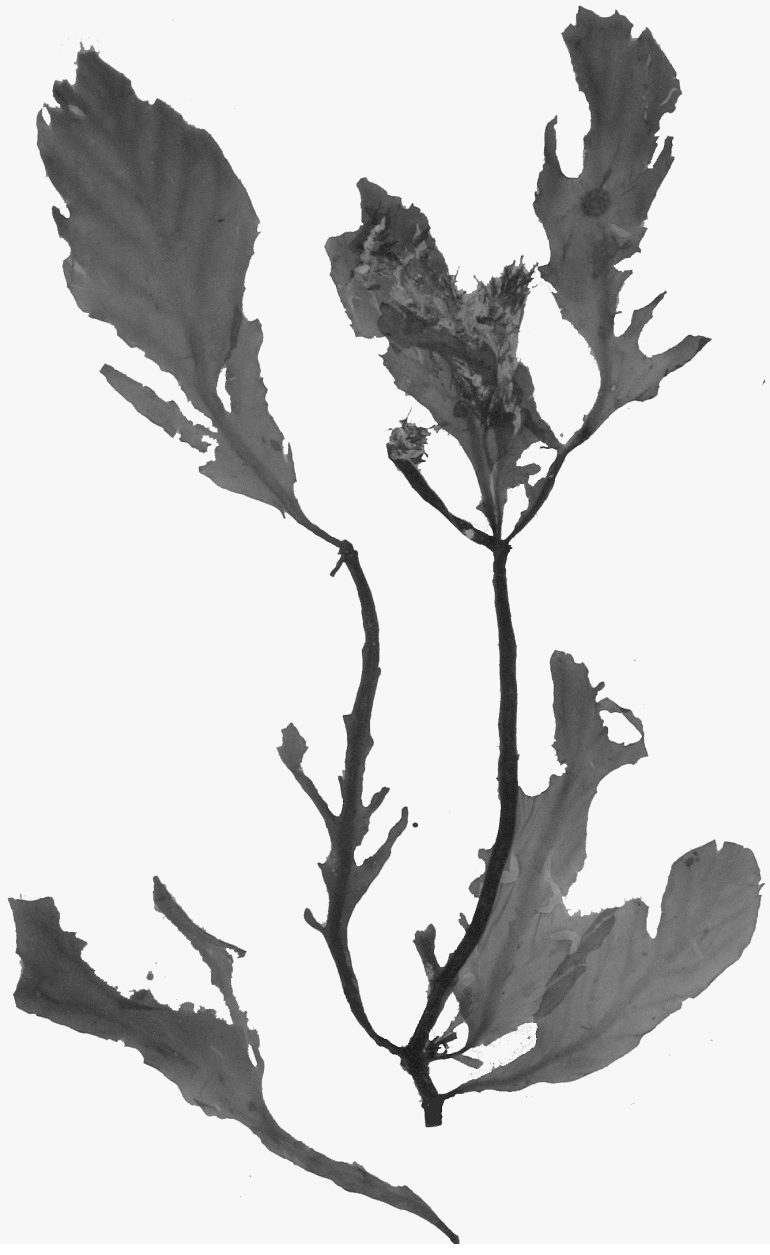

FIG. 1. Specimen of "Palmetta aleutica Tilesius" ined. In MEL.

language and married a native of that region, but he died in 1797. Sarychev (1807) stated that Merck's journal with his observations and research was turned over to Pallas, the celebrated botanist and zoologist who had explored many regions of Russia (Pallas, 1776, 1784-88, 1802-03; Masterson and Brower, 1948). According to Pierce (cited in Merck, 1980), Pallas was not able to make full use of Merck's journal because he left Russia in 1810 and died in Berlin the following year. Pierce thought that Merck's journal was most likely among the unnoticed papers left behind with Pallas' possessions, until it was finally noticed, acquired by a Berlin book dealer, and later sold to a book dealer in Leipzig. Eventually, an incomplete journal was translated and published (Merck, 1980).

The specimen collected by Merck from Unalaska (Fig. 1) and later depicted by Tilesius (Fig. 2) and given the name Palmetta aleutica ined. can be identified as Mikamiella ruprechtiana (Zinova) M.J. Wynne. This species was first described by Zinova (1965) as Hypophyllum ruprechtianum from St. Paul Island, Pribilof Islands, in the Bering Sea. Zinova's type specimen had been collected by Alexander Postels on the Lütke Expedition of 1826-29 (Pierce, 1987) and had been misidentified as "Delesseria crassifolia" [= Yendonia crassifolia (Ruprecht) Kylin], a red algal species

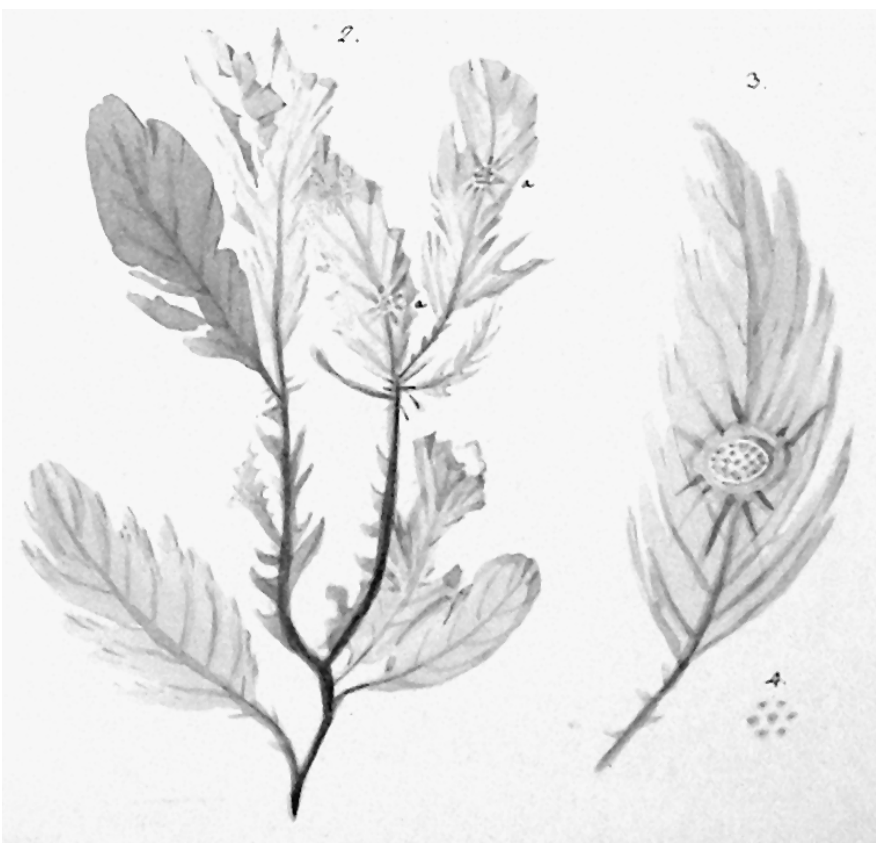

FIG. 2. Water-colored illustration of the specimen, prepared by Tilesius.

of the same family also first described from St. Paul Island (Ruprecht, 1851). Hypophyllum ruprechtianum later served as the type species of the new genus Mikamiella established by Wynne (1977). This species has also been reported from the far eastern shores of Russia (Perestenko, 1988, 1994), as well as from the Commander Islands (Selivanova and Zhigadlova, 1997) and from the Aleutians (Wynne, 1970) to southern Southeast Alaska (Scagel et al., 1989). The label prepared by Tilesius includes his reference to "cum 2 fructicationibus," and these structures are conspicuous both on the actual specimen and in the illustration. These objects, however, are not reproductive organs belonging to the alga, but epiphytic invertebrates.

Other algal specimens in MEL accompanied by Tilesius' illustrations include three species of Sargassum-S. horneri (Turner) C. Agardh, S. piluliferum (Turner) C. Agardh, and S. serratifolium (C. Agardh) C. Agardh, all from northern Japan-and the red alga Tichocarpus crinitus (S.G. Gmelin) Ruprecht from Kamchatka. Another red alga labeled "Iridaea?" is said to be a Tilesius collection from Unalaska; however, its identity remains uncertain. Another of these plates in MEL depicts an alga that Tilesius had collected in 1805 in the harbor of Nagasaki, Japan. That alga, a perforate blade, was later described as the new genus and species Talarodictyon tilesii by Endlicher (1843), and the name was long regarded as of uncertain status and taxonomic assignment. The type specimen of Talarodictyon tilesii was also present in the holdings of MEL. Sinkora and Wynne (1990) were able to present evidence that $T$. tilesii was a junior taxonomic synonym of the widely occurring tropical brown alga Hydroclathrus clathratus (C. Agardh) M. Howe.

Tilesius (1813) published many of his observations made during the voyage with von Krusenstern. Tilesius' plants 
were left to the herbaria of K.F. Ledebour and F.E.L. von Fischer, after whose deaths they ended up in the collections of the Botanical Garden of St. Petersburg (McKelvey, 1991). According to Moessner's Endnote 445n.30 (in Löwenstern, 2003), a part of Tilesius' diary of the voyage still exists in the archives of Mühlhausen, Germany, his birthplace. Although Tilesius did not publish descriptions of his algal collections, at least some of them ended up in the hands of C. Agardh in Lund, Sweden. Agardh (1812) described several species on the basis of specimens collected by Tilesius in the Sea of Japan or the Japanese Archipelago, such as Fucus tilesii [= Coccophora langsdorfii (Turner) Grev.], F. filifolius, and F. pinnatifolius $[=$ Sargassum pinnatifolium (C. Agardh) C. Agardh]. He also described F. evanescens from Sakhalin (Agardh, 1821a, b) and F. tubulosus nom. illeg. from Kamchatka (Agardh, 1822). It seems worthwhile to draw attention to the existence of these marine algae from the remote North Pacific, collected by early Russian expeditions and accompanied by illustrations made by Tilesius, and to the fact that they are now deposited in the National Herbarium of Victoria.

\section{ACKNOWLEDGEMENTS}

The images are reproduced with permission from the State Botanical Collection, National Herbarium of Victoria (MEL). I wish to express my gratitude to Dr. Josephine (Pina) Milne, Acting Collections Manager, and Dr. Catherine Gallagher, Curation Coordinator, both at MEL, for kindly locating the specimen and plate of Palmetta aleutica and arranging to have them scanned and the images sent to me. Mr. David Bay kindly assisted me in preparing the figures. I thank Dr. Craig W. Schneider of Trinity College, Hartford, Connecticut, for reviewing the manuscript.

\section{REFERENCES}

AGARDH, C.A. 1812. Algarum decas prima. Lundae: Litteris Berlingianis. 15 p., 1 pl.

- 1821a. Species algarum rite cognitae: cum synonymis, differentiis specificis et descriptionibus succinctis. Vol. 1, part 1. Gryphiswaldiae [Griefswald, Germany]: Sumtibus Ernesti Mauritii. 1-168.

. 1821b. Icones algarum ineditae. Fasciculus secundus. Pls. XI-XX. Holmiae: Officina Ecksteiniana.

- 1822. Species algarum. Vol. 1, part 2. Lund: Berlingiana. $169-531$.

DUCKER, S.C. 1981. Australian phycology: The German influence. In: Carr, D.J., and Carr, S.G.M., eds. People and plants in Australia. Sydney: Academic Press. 116-138.

ENDLICHER, S.L. 1843. Genera plantarum. Mantissa botanica altera. Sistens genera plantarum supplementum tertium. Vinobonae [Vienna]: F. Beck. 111 p.

HULTÉN, E. 1937. Flora of the Aleutian Islands and westernmost Alaska Peninsula with notes on the flora of Commander Islands. Stockholm: Bokförlags Aktiebolaget Thule. 397 p., 16 pls.
- 1940. History of botanical exploration in Alaska and Yukon Territories from the time of their discovery to 1940. Botaniska Notiser 1940:289-346.

1960. Flora of the Aleutian Islands and westernmost Alaska Peninsula with notes on the flora of Commander Islands. 2nd ed. Weinheim: J. Cramer. 376 p.

KRUSENSTERN, A.J. von. 1813. Voyage round the world in the years 1803, 1804, 1805, and 1806, by order of his Imperial Majesty Alexander the First, on board the Nadeshda and Neva under the command of Captain A.J. von Krusenstern of the Imperial Navy. 2 vols. London: J. Murray. Translated from the original German by R.B. Hoppner. [Re-issue of the London translation, Amsterdam: N. Israel; and New York: Da Capo Press. 1968].

LANGSDORFF, G.H. von. $1813-14$. Voyage and travels in various parts of the world, during the years 1803, 1804, 1805, 1806, and 1807. 2 vols. London: H. Colburn. [Translation of the author's "Bemerkungen auf einer Reise um die Welt," Frankfurt am Mayn, 1812.]

- 1993. Remarks and observations on a voyage around the world from 1803 to 1807 . Vol. 1. Translated and annotated by V.J. Moessner and edited by R.A Pierce. Kingston, Ontario, and Fairbanks, Alaska: Limestone Press. 281 p.

LÖWENSTERN, H. L. von. 2003. The first Russian voyage around the world. The journal of Hermann Ludwig von Löwenstern, 1803-1806. Translated by V.J. Moessner. Fairbanks: University of Alaska Press. 482 p.

MASTERSON, J.R., and BROWER, H. 1948. Bering's successors, 1745-1780: Contributions of Peter Simon Pallas to the history of Russian exploration toward Alaska. Seattle: University of Washington Press. 96 p.

McKELVEY, S.D. 1991. Botanical exploration of the TransMississippi West 1790-1850. Foreword by J. Ewan and introduction by S.D. Beckham. Reprint. Corvallis: Oregon State University Press. 1144 p.

MERCK, C.H. 1980. Siberia and northwestern America 1788 1792. The journal of Carl Heinrich Merck, naturalist with the Russian scientific expedition led by Captains Joseph Billings and Gavriil Sarychev. Translated by F. Jaensch and edited by R.A. Pierce. Materials for the Study of Alaska History, No. 17. Kingston, Ontario: Limestone Press. 215 p.

PALLAS, P.S. 1776. Reise durch verschiedene Provinzen der Russischen Reichs, Part 3. St. Petersburg: Kayserlichen Academie der Wissenshaften.

- 1784-88. Flora Rossica; seu, Strirpium Imperii rossici per Europarum et Asiam indigenarum descriptiones et icones. Petropoli [St. Petersburg] e Typographia imperiale J.J. Weitbrecht. Vol. 1, Part 1, 1784; Vol. 1, Part 2, 1788.

. 1802-03. Travels through the southern provinces of the Russian Empire, in the years 1793 and 1794. 2 vols. Translated from the German. London: Longman \& Rees.

PERESTENKO, L.P. 1988. Additions to the flora of red algae from Bering Sea. Novitates Systematicae Plantarum non Vascularium 25:54-57. [In Russian.]

- 1994. Krasnye vodorosli dal'nevostochnykh morei Rossii [Red algae of the Far Eastern seas of Russia]. St. Petersburg: “Olga" Publishing House. 331 p. [In Russian.] 
PIERCE, R.A., ed. 1987. A voyage around the world 1826-1829. Vol. I. To Russian America and Siberia, by Frederic Litke. Kingston, Ontario: Limestone Press. 230 p. Translated from the French edition by Reneé Marshall, supplemented with a parallel account by E. H. Baron von Kittlitz, translated from the German, with an introduction by Dr. Joan Moessner.

ROWELL, M. 1973. Early Russian botanical exploration in the North Pacific. Episteme [Milan, Italy] 7:165-185.

RUPRECHT, F.J. 1851. Tange des Ochotskischen. Meeres. In: A. Th. von Middendorff's Reise in den äussersten Norden und Osten Sibiriens während der Jahre 1843 und 1844.... Vol. 1(2): 191-435. St. Petersburg: Buchdrucherei der Kaiserlichen Akademie der Wissenschaften.

SARYCHEV, G.A. [G. SARYTSCHEW]. 1806-07. Account of a voyage of discovery to the north-east of Siberia, the frozen ocean, and the north-east sea. Translated from the Russian and embellished with engravings. Vol. 1, 1806; Vol. 2, 1807. London: J.G. Bernard.

SAUER, M. 1802. An account of a geographical and astronomical expedition to the northern parts of Russia, for ascertaining the degrees of latitude and longitude of the mouth of the river Kovima; of the whole coast of the Tshutski, to East Cape; and of the islands in the eastern ocean, stretching to the American coast, performed ... by Commodore Joseph Billings, in the years 1785, \&c. to 1794. London: T. Cadell, Jun. and W. Davies. 332 p.

SCAGEL, R.F., GABRIELSON, P.W., GARBARY, D.J., GOLDEN, L., HAWKES, M.W., LINDSTROM, S.C., OLIVEIRA, J.C., and WIDDOWSON, T.B. 1989. A synopsis of the benthic marine algae of British Columbia, southeast Alaska, Washington and Oregon. Phycological Contribution No. 3. Vancouver: Dept. of Botany, University of British Columbia. $532 \mathrm{p}$.
SEEMAN, B. 1857. [Obituary of W.G. Tilesius von Tilenau.] Bonplandia 5:225-226.

SELIVANOVA, O.N., and ZHIGADLOVA, G.G. 1997. Marine algae of the Commander Islands, III. Rhodophyta. Botanica Marina 40:15-24.

SINKORA, D.M., and WYNNE, M.J. 1990. On the identity of Talarodictyon tilesii Endlicher. Japanese Journal of Phycology 38:383-386.

TIKHMENEV, P.A. 1978. A history of the Russian-American Company. Translated and edited by R.A. Pierce and A.S. Donnelly, Seattle: University of Washington Press. 522 p.

TILESIUS VON TILENAU, W.G. 1813. Naturhistorische Früchte der ersten Kaiserlich-Russischen, unter dem Kommando des Herrn v. Krusenstern glücklich vollbrachten Erdumsegelung gesammelt von Dr. Tilesius naturlisten der Expedition... [Natural historical observations from the first completed Imperial Russian Circumnavigation of the world under the command of von Krusenstern]. St. Petersburg. 130 p., 5 pls. [Not seen.] [A reissue, under a separate title page, of a portion of Thl. III of A.J. von Krusenstern's "Reise um die Welt in den Jahren 18031806".]

WYNNE, M.J. 1970. Marine algae of Amchitka Island (Aleutian Islands). I. Delesseriaceae. Syesis 3:95-144.

1977. Mikamiella, a new genus of Delesseriaceae (Rhodophyta) from the North Pacific. Bulletin of the Japanese Society of Phycology 25(Suppl.):395-402.

ZINOVA, A.D. 1965. Species familiae Delesseriacearum (Rhodophyta) in parte septentrionali Oceani Pacifici. Novitates Systematicae Plantarum non Vascularium 1965:78-97. 